\title{
Ultrasound-Assisted Synthesis, Antioxidant Activity and Computational Study of 1,3,4-Oxadiazol-2-amines
}

\author{
Hamid Beyzaei, ${ }^{1 \star}$ Soheila Sargazi, ${ }^{2}$ Ghodsieh Bagherzade, ${ }^{2}$ Ashraf Moradi, ${ }^{1}$ \\ and Elahe Yarmohammadi ${ }^{1}$ \\ ${ }^{1}$ Department of Chemistry, Faculty of Science, University of Zabol, Zabol, Iran \\ ${ }^{2}$ Department of Chemistry, Faculty of Science, University of Birjand, Birjand, Iran \\ *Corresponding author:E-mail: hbeyzaei@yahoo.com and hbeyzaei@uoz.ac.ir \\ Tel: +985431232186/ Fax: +985431232180
}

Received: 06-19-2020

\begin{abstract}
Development of synthetic procedures for the preparation of 1,3,4-oxadiazole derivatives has always been in the interest of researchers as a result of their widespread biological activities. In this study, an ultrasound-assisted procedure was proposed for the synthesis of 1,3,4-oxadiazol-2-amines form the reaction of hydrazides and cyanogen bromide. They were efficiently produced in $81-93 \%$ yields in the presence of ethanol and potassium bicarbonate as the reaction media and the base, respectively. Their antioxidant properties were determined via DPPH free radical scavenging method as one of the most basic steps in identifying other related biological effects. IC $_{50}$ values were in the range of from 0.237 to 0.863 $\mathrm{mM}$. The synthesized 1,3,4-oxadiazoles are protective agents against oxidative stress, and can be used in the treatment of cancer, candidiasis, diabetes, neurodegenerative and inflammatory diseases. Furthermore, bond dissociation energies (BDEs) and electron densities based NCI (non-covalent interactions) were calculated using density-functional theory (DFT) to understand the observed reactivities. It was found that reversible dipole-dipole forces play a key role in most interactions.
\end{abstract}

Keywords: 1,3,4-Oxadiazole; Antioxidant activity; DPPH; Ultrasound irradiation; NCI; DFT

\section{Introduction}

Antioxidants are synthetic or natural compounds that inhibit the oxidation reactions via free radical scavenging. Free radicals are unstable and reactive atoms or molecules containing one unpaired electron that can begin a propagation sequence in the chain reactions leading to cell damage. ${ }^{1}$ Vitamins $\mathrm{C}$ and $\mathrm{E}$ as two essential nutrients are well known for being potent antioxidants. Ascorbic acid, known as vitamin C, is a water-soluble biologically active compound which should be provided to humans through food especially fresh vegetables and citrus fruits. Lack of vitamin $\mathrm{C}$ is accompanied by early symptoms of weakness and fatigue which can lead to anemia, hair loss, bleeding gum and skin, and scurvy disease in the acute cases. ${ }^{2}$ Vitamin $\mathrm{C}$ is required for the proper functioning of some enzymes and immune system, tissue regeneration and the enzymatic production. ${ }^{3-5}$ Oil-soluble vitamin $\mathrm{E}$ includes four tocopherols as well as four tocotrienols. It is found in cereals, vegetable oils, meat, poultry, fruits and eggs, and its deficiency damages the nervous system. ${ }^{6}$
It has been understood that there is a significant relationship between the antioxidant capacity of compounds and some of their biological activities. Mendonca et al. have evaluated antioxidant and antiproliferative potentials of muscadine grape extracts on breast cancer cell lines; a strong positive correlation was observed between total phenolic content of extracts and their inhibitory activities against African American breast cancer cells. ${ }^{7}$ There are complex and often positive connections between oxidative stress with the inflammatory response given as a result of tissue injury and infection. ${ }^{8}$ Guava leaves are used as traditional medicines for the treatment of diabetes; they lowered levels of cholesterol, sugar, triglycerides, malonaldehyde and glycated serum protein in the blood of streptozotocin-induced diabetic mice according to their ABTS, $\mathrm{OH}$ and DPPH free radical scavenging capabilities. ${ }^{9}$ Reactive oxygen species are one of the main causes of Alzheimer disease, as a result, any agent that blocks their generation, can be useful in treating the disease. ${ }^{10}$

1,3,4-Oxadiazole derivatives have attracted a great deal of interest due to their diverse biological properties 
such as antioxidant, antiproliferative, anticonvulsant, antimicrobial and anti-Alzheimer. ${ }^{11-15}$ Synthetic approaches of 1,3,4-oxadiazoles were reviewed in several literatures. ${ }^{16-18}$ Hypervalent iodine mediated reaction of $N^{\prime}$-arylidene acetohydrazides, intracyclocondensation of thiosemicarbazides prepared from the reaction of aryl hydrazides with ammonium thiocyanate using $N, N, N^{\prime}, N^{\prime}$-tetramethyl$O$-(benzotriazol-1-yl)uronium tetrafluoroborate (TBTU) or $N, N^{\prime}$-diisopropylcarbodiimide (DIC), and simultaneous reaction of 1-chloroketones, $\mathrm{N}$-isocyaniminotriphenylphosphorane and aryl carboxylic acids are examples of recent methods proposed to synthesize 1,3,4-oxadiazole derivatives. ${ }^{19-21}$

Theoretical calculations can be performed to justify experimental observations. However, it is possible that a logical relationship between experimental data and theoretical parameters cannot be found in all cases. The thermodynamics of free radical scavenge of some 1,3,4-oxadiazole derivatives were studied by DFT method in gas and aqueous phases to predict their action mechanisms; it was found that the selected reaction pathway is completely dependent on the reaction medium. ${ }^{22}$

It has been shown that phenolic compounds act as antioxidants in three ways (Scheme 1):

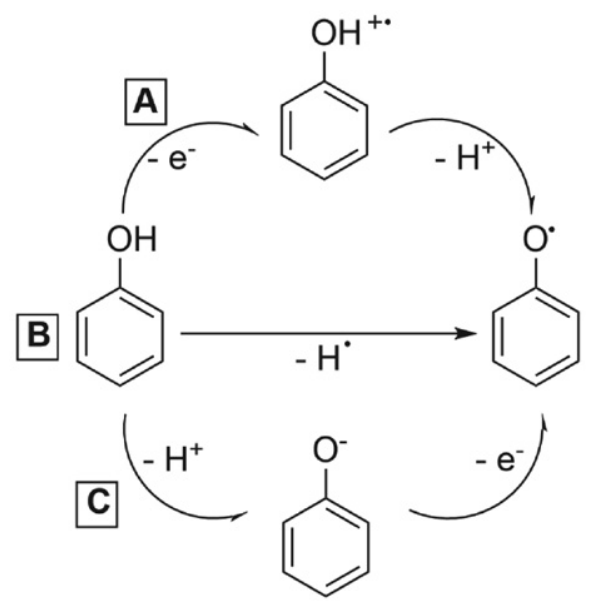

Scheme 1. Antioxidant mechanism of phenolic compounds: (A) Single Electron Transfer Followed by Proton Transfer (SET-PT); (B) Hydrogen Atom Transfer (HAT); (C) Sequential Proton Loss Electron Transfer (SPLET).

Computational studies can be applied to calculate values of bond dissociation enthalpy, ionization potential and proton dissociation enthalpy, proton affinity and electron transfer enthalpy to determine the predominant path. ${ }^{23} \mathrm{DPPH}$ free radical scavenging activity of some synthesized 1,2,4-triazole-3-thiones containing phenolic substituents was evaluated by Ivanović et al.; DFT calculations proved synergistic effects of 1,2,4-triazole-3-thione rings and predicted SPLET pathway as the action mechanism in methanol. ${ }^{23}$
In order to expand library of small organic biomolecules, some 5-alkyl/aryl/heteroaryl-1,3,4-oxadiazol2 -amine derivatives were synthesized via a new procedure under ultrasound irradiation. Antioxidant activities of the synthesized 1,3,4-oxadiazoles were assessed against DPPH to predict their other possible biological capabilities. Bond dissociation energy and electron density of all synthesized heterocycles were calculated to establish the probable relation to the observed antioxidant activities.

\section{Experimental}

\section{1. Chemicals}

All chemicals, solvents and aluminium thin-layer chromatography (TLC) plates pre-coated with silica gel containing fluorescent indicator F254 were purchased from Merck and Sigma-Aldrich companies. The melting points were determined with Kruss KSP1N melting point apparatus, and are uncorrected. Bruker Tensor-27 FT-IR spectrometer was applied to record the FT-IR spectra of compounds. ${ }^{1} \mathrm{H}$ and ${ }^{13} \mathrm{C}$ NMR spectra were registered using a Bruker $300 \mathrm{MHz}$ NMR spectrometer. Chemical shifts are provided as $\delta$ values (ppm) and coupling constants $J(\mathrm{~Hz})$. Elemental analyses for $\mathrm{C}, \mathrm{H}, \mathrm{N}$ and $\mathrm{S}$ atoms were performed on a Termo Finnigan Flash EA microanalyzer. Ultrasonic irradiation was supplied by Backer vCLEAN1-L03 $(40 \mathrm{kHz}$ frequency and $100 \mathrm{~W}$ output power).

\section{1. 1. General Procedure for the Synthesis of 5-Substituted 1,3,4-Oxadiazol-2-amines 3a-h}

A $25 \mathrm{~mL}$ round-bottom flask containing $5 \mathrm{mmol}$ of each hydrazides $\mathbf{1 a}-\mathbf{h}$, cyanogen bromide (2) $(0.53 \mathrm{~g})$ and potassium bicarbonate $(0.50 \mathrm{~g})$ in $10 \mathrm{~mL}$ absolute ethanol was subjected to an ultrasonic bath. The reaction progress was checked by TLC with different volumetric ratios of methanol and dichloromethane as the desired mobile phase. The reaction content was added to $20 \mathrm{~g}$ of crushed ice containing an excess of salt. The solid phase was filtered out, washed respectively with water $(5 \mathrm{~mL})$ and ethanol $(5 \mathrm{~mL})$, and oven-dried at $70{ }^{\circ} \mathrm{C}$ to give pure $1,3,4$-oxadiazoles $\mathbf{3 a}-\mathbf{h}$.

\section{5-Methyl-1,3,4-oxadiazol-2-amine (3a).}

Yellow powder; yield $0.40 \mathrm{~g}(81 \%)$; m.p. $172-174{ }^{\circ} \mathrm{C}$ (lit. m.p. $\left.176-180^{\circ} \mathrm{C}^{24}\right)$; IR ( $\left.\mathrm{KBr}\right) v 3420,3352\left(\mathrm{NH}_{2}\right)$, 3120, 2359, $1666(\mathrm{C}=\mathrm{N}), 1595,1383,1254,1123(\mathrm{C}-$ O), $1005(\mathrm{~N}-\mathrm{N}), 781,626 \mathrm{~cm}^{-1}$; ${ }^{1} \mathrm{H}$ NMR $(300 \mathrm{MHz}$, DMSO- $\left.d_{6}\right) \delta 6.85\left(\mathrm{~s}, 2 \mathrm{H}, \mathrm{NH}_{2}\right), 2.27\left(\mathrm{~s}, 3 \mathrm{H}, \mathrm{CH}_{3}\right) ;{ }^{13} \mathrm{C}$ NMR $\left(75 \mathrm{MHz}, \mathrm{DMSO}-d_{6}\right) \delta 10.9\left(\mathrm{CH}_{3}\right), 156.6(\mathrm{C}-5$ oxadiazole), 164.0 (C-2 oxadiazole). Anal. Calcd. for $\mathrm{C}_{3} \mathrm{H}_{5} \mathrm{~N}_{3} \mathrm{O}: \mathrm{C}, 36.36 ; \mathrm{H}, 5.09 ; \mathrm{N}, 42.41$. Found: C, 36.31; $\mathrm{H}, 5.11 ; \mathrm{N}, 42.43$. 
5-Phenyl-1,3,4-oxadiazol-2-amine (3b).

White powder; yield $0.74 \mathrm{~g}$ (92\%); m.p. 243-245 ${ }^{\circ} \mathrm{C}$ (lit. m.p. $\left.239-242{ }^{\circ} \mathrm{C}^{25}\right)$; IR ( $\left.\mathrm{KBr}\right)$ v 3476, $3413\left(\mathrm{NH}_{2}\right)$, 2924, 2358, $1613(\mathrm{C}=\mathrm{N}), 1452,1113(\mathrm{C}-\mathrm{O}), 1027(\mathrm{~N}-\mathrm{N})$, $620,478 \mathrm{~cm}^{-1}$; ${ }^{1} \mathrm{H}$ NMR $\left(300 \mathrm{MHz}, \mathrm{DMSO}-d_{6}\right) \delta 7.25$ (s, $2 \mathrm{H}, \mathrm{NH}_{2}$ ), 7.80-7.78 (m, 2H, H-2',6' Ph), 7.51-7.49 (m, $\left.3 \mathrm{H}, \mathrm{H}-3^{\prime}, 4^{\prime}, 5^{\prime} \mathrm{Ph}\right) ;{ }^{13} \mathrm{C}$ NMR $\left(75 \mathrm{MHz}, \mathrm{DMSO}-d_{6}\right) \delta$ $124.8\left(\mathrm{C}-1^{\prime} \mathrm{Ph}\right), 125.4\left(\mathrm{C}-2^{\prime}, 6^{\prime} \mathrm{Ph}\right), 129.6\left(\mathrm{C}-3^{\prime}, 5^{\prime} \mathrm{Ph}\right)$, 130.7 (C-4' Ph), 157.8 (C-5 oxadiazole), 164.3 (C-2 oxadiazole). Anal. Calcd. for $\mathrm{C}_{8} \mathrm{H}_{7} \mathrm{~N}_{3} \mathrm{O}: \mathrm{C}, 59.62 ; \mathrm{H}, 4.38 ; \mathrm{N}$, 26.07. Found: C, 59.59; H, 4.35; N, 26.11.

\section{5-(4-Nitrophenyl)-1,3,4-oxadiazol-2-amine (3c).}

Yellow powder; yield $0.91 \mathrm{~g}(88 \%)$; m.p. $265-267$ ${ }^{\circ} \mathrm{C}$ (lit. m.p. 267-270 $\left.{ }^{\circ} \mathrm{C}^{25}\right)$; IR (KBr) v 3436, $3375\left(\mathrm{NH}_{2}\right)$, 2924, 2358, $1652(\mathrm{C}=\mathrm{N}), 1598(\mathrm{~N}-\mathrm{O}), 1527,1389,1344$, $1116(\mathrm{C}-\mathrm{O}), 1037(\mathrm{~N}-\mathrm{N}), 858,620 \mathrm{~cm}^{-1}$; ${ }^{1} \mathrm{H}$ NMR (300 $\left.\mathrm{MHz}, \mathrm{DMSO}-d_{6}\right) \delta 7.52$ (brs, $\left.2 \mathrm{H}, \mathrm{NH}_{2}\right), 8.32(\mathrm{~d}, J=8.7$ $\left.\mathrm{Hz}, 2 \mathrm{H}, \mathrm{H}-3^{\prime}, 5^{\prime} \mathrm{Ar}\right), 7.98$ (d, $J=8.7 \mathrm{~Hz}, 2 \mathrm{H}, \mathrm{H}-2^{\prime}, 6^{\prime} \mathrm{Ar}$ ); ${ }^{13} \mathrm{C}$ NMR $\left(75 \mathrm{MHz}\right.$, DMSO- $\left.d_{6}\right) \delta 124.9\left(\mathrm{C}-3^{\prime}, 5^{\prime} \mathrm{Ar}\right), 126.4$ (C-2',6' Ar), 130.2 (C-1' Ar), 148.3 (C-4' Ar), 156.5 (C-5 oxadiazole), 165.0 (C-2 oxadiazole). Anal. Calcd. for $\mathrm{C}_{8} \mathrm{H}_{6} \mathrm{~N}_{4} \mathrm{O}_{3}$ : C, 46.61; H, 2.93; N, 27.18. Found: $\mathrm{C}, 46.66 ; \mathrm{H}$, $2.93 ; \mathrm{N}, 27.15$.

\section{5-(4-(tert-Butyl)phenyl)-1,3,4-oxadiazol-2-amine (3d).}

Pink powder; yield $1.01 \mathrm{~g}$ (93\%); m.p. $262-264{ }^{\circ} \mathrm{C}$ (lit. m.p. 256-258 $\left.{ }^{\circ} \mathrm{C}^{25}\right)$; IR $(\mathrm{KBr})$ v 3434, $3358\left(\mathrm{NH}_{2}\right)$, 3127, 2963, 2358, $1655(\mathrm{C}=\mathrm{N}), 1609,1391,1118(\mathrm{C}-\mathrm{O})$, $1042(\mathrm{~N}-\mathrm{N}), 836,621,561 \mathrm{~cm}^{-1} ;{ }^{1} \mathrm{H}$ NMR $(300 \mathrm{MHz}$, DMSO- $\left.d_{6}\right) \delta 7.55$ (brs, $\left.2 \mathrm{H}, \mathrm{NH}_{2}\right), 7.83(\mathrm{~d}, J=8.5 \mathrm{~Hz}, 2 \mathrm{H}$, $\mathrm{H}-2^{\prime}, 6^{\prime} \mathrm{Ar}$ ), 7.63 (d, $J=8.5 \mathrm{~Hz}, 2 \mathrm{H}, \mathrm{H}-3^{\prime}, 5^{\prime} \mathrm{Ar}$ ), 1.34 $\left(\mathrm{s}, 9 \mathrm{H}, 3 \times \mathrm{CH}_{3}\right) ;{ }^{13} \mathrm{C}$ NMR $\left(75 \mathrm{MHz}, \mathrm{DMSO}-d_{6}\right) \delta 31.1$ $\left(\mathrm{C}\left(\mathrm{CH}_{3}\right)_{3}\right), 35.0\left(\underline{\mathrm{C}}\left(\mathrm{CH}_{3}\right)_{3}\right), 121.4\left(\mathrm{C}-3^{\prime}, 5^{\prime} \mathrm{Ar}\right), 125.0(\mathrm{C}-$ 2',6' Ar), 127.2 (C-1' Ar), 152.6 (C-4' Ar), 157.5 (C-5 oxadiazole), 164.3 (C-2 oxadiazole). Anal. Calcd. for $\mathrm{C}_{12} \mathrm{H}_{15} \mathrm{~N}_{3} \mathrm{O}$ : C, 66.34; H, 6.96; N, 19.34. Found: C, 66.30; $\mathrm{H}, 6.98 ; \mathrm{N}, 19.36$.

\section{3-(5-Amino-1,3,4-oxadiazol-2-yl)phenol (3e).}

White powder; yield $0.73 \mathrm{~g}(83 \%)$; m.p. $240-242{ }^{\circ} \mathrm{C}$ (lit. m.p. $\left.244-245^{\circ} \mathrm{C}^{26}\right)$; IR (KBr) v $3554(\mathrm{OH}), 3458,3413$ $\left(\mathrm{NH}_{2}\right), 3145,2924,2360,2341,1643(\mathrm{C}=\mathrm{N}), 1601,1568$, $1493,1384,1320,1309,1221,1126(\mathrm{C}-\mathrm{O}), 1064(\mathrm{~N}-\mathrm{N})$, $1035,994,876,799,739,701,688,669,617,450 \mathrm{~cm}^{-1} ;{ }^{1} \mathrm{H}$ NMR $\left(300 \mathrm{MHz}, \mathrm{DMSO}-d_{6}\right) \delta 9.90(\mathrm{~s}, 1 \mathrm{H}, \mathrm{OH}), 7.35-7.26$ $\left(\mathrm{m}, 5 \mathrm{H}, \mathrm{NH}_{2}, \mathrm{H}-2^{\prime}, 5^{\prime}, 6^{\prime} \mathrm{Ar}\right), 6.91\left(\mathrm{~d}, J=6.9 \mathrm{~Hz}, 1 \mathrm{H}, \mathrm{H}-4^{\prime}\right.$ Ar); ${ }^{13} \mathrm{C}$ NMR (75 MHz, DMSO- $\left.d_{6}\right) \delta 112.0$ (C-2' Ar), 116.3 (C-4' Ar), 118.0 (C-6' Ar), 125.8 (C-1' Ar), 130.8 (C-5' Ar), 157.9 (C-3' Ar), 158.2 (C-5 oxadiazole), 164.2 (C-2 oxadiazole). Anal. Calcd. for $\mathrm{C}_{8} \mathrm{H}_{7} \mathrm{~N}_{3} \mathrm{O}_{2}: \mathrm{C}, 54.24 ; \mathrm{H}$, 3.98; N, 23.72. Found: C, 54.19; H, 3.96; N, 23.75.

\section{5-(3-Methoxyphenyl)-1,3,4-oxadiazol-2-amine (3f).}

Yellow powder; yield $0.86 \mathrm{~g}$ (90\%); m.p. 193-194 ${ }^{\circ} \mathrm{C}$ (lit. m.p. 192-195 $\left.{ }^{\circ} \mathrm{C}^{27}\right)$; IR (KBr) v 3415, $3386\left(\mathrm{NH}_{2}\right)$,
3109, 2359, $1654(\mathrm{C}=\mathrm{N}), 1489,1390,1322,1284,1215$, $1106(\mathrm{C}-\mathrm{O}), 1040(\mathrm{~N}-\mathrm{N}), 875,786,748,683,621 \mathrm{~cm}^{-1}$; ${ }^{1} \mathrm{H}$ NMR $\left(300 \mathrm{MHz}\right.$, DMSO- $\left.d_{6}\right) \delta 7.48-7.38(\mathrm{~m}, 2 \mathrm{H}$, H-5', 6'), 7.31-7.30 (m, 3H, $\mathrm{NH}_{2}, \mathrm{H}-2^{\prime} \mathrm{Ar}$ ), 7.10 (d, $J=7.0$ $\left.\mathrm{Hz}, 1 \mathrm{H}, \mathrm{H}-4{ }^{\prime} \mathrm{Ar}\right), 3.83$ (s, 3H, $\left.\mathrm{CH}_{3}\right) ;{ }^{13} \mathrm{C} \mathrm{NMR}(75 \mathrm{MHz}$, DMSO- $\left.d_{6}\right) \delta 55.7\left(\mathrm{CH}_{3}\right), 110.3\left(\mathrm{C}-2^{\prime} \mathrm{Ar}\right), 116.8\left(\mathrm{C}-4^{\prime} \mathrm{Ar}\right)$, 117.8 (C-6' Ar), 126.6 (C-1' Ar), 130.9 (C-5' Ar), 157.7 (C-3' Ar), 160.0 (C-5 oxadiazole), 164.3 (C-2 oxadiazole). Anal. Calcd. for $\mathrm{C}_{9} \mathrm{H}_{9} \mathrm{~N}_{3} \mathrm{O}_{2}: \mathrm{C}, 56.54 ; \mathrm{H}, 4.75 ; \mathrm{N}, 21.98$. Found: C, 54.59; H, 4.74; N, 21.95.

\section{5-(3-Bromophenyl)-1,3,4-oxadiazol-2-amine (3g).}

White powder; yield $1.10 \mathrm{~g}$ (92\%); m.p. 246-248 ${ }^{\circ} \mathrm{C}$ (lit. m.p. $\left.240-243{ }^{\circ} \mathrm{C}^{27}\right)$; IR ( $\left.\mathrm{KBr}\right)$ v 3451, $3413\left(\mathrm{NH}_{2}\right)$, 3116, 2358, $1654(\mathrm{C}=\mathrm{N}), 1604,1557,1392,1112(\mathrm{C}-\mathrm{O})$, $1044(\mathrm{~N}-\mathrm{N}), 794,681 \mathrm{~cm}^{-1}$; ${ }^{1} \mathrm{H}$ NMR $(300 \mathrm{MHz}, \mathrm{DM}-$ SO- $\left.d_{6}\right) \delta 7.91\left(\mathrm{~m}, 1 \mathrm{H}, \mathrm{H}-6^{\prime}\right), 7.80\left(\mathrm{~d}, J=7.8 \mathrm{~Hz}, 1 \mathrm{H}, \mathrm{H}-4^{\prime}\right.$ Ar), $7.71\left(\mathrm{~d}, J=7.7 \mathrm{~Hz}, 1 \mathrm{H}, \mathrm{H}-2^{\prime} \mathrm{Ar}\right), 7.50(\mathrm{t}, J=7.5 \mathrm{~Hz}$, $\left.1 \mathrm{H}, \mathrm{H}-5^{\prime} \mathrm{Ar}\right), 7.38$ (s, $\left.2 \mathrm{H}, \mathrm{NH}_{2}\right) ;{ }^{13} \mathrm{C}$ NMR $(75 \mathrm{MHz}, \mathrm{DM}-$ SO- $\left.d_{6}\right) \delta 122.7$ (C-3' Ar), 124.4 (C-6' Ar), 126.9 (C-1' Ar), 127.7 (C-4' Ar), 131.9 (C-5' Ar), 133.4 (C-2' Ar), 156.4 (C-5 oxadiazole), 164.5 (C-2 oxadiazole). Anal. Calcd. for $\mathrm{C}_{8} \mathrm{H}_{6} \mathrm{BrN}_{3} \mathrm{O}: \mathrm{C}, 40.03 ; \mathrm{H}, 2.52 ; \mathrm{N}, 17.50$. Found: $\mathrm{C}$, $40.01 ; \mathrm{H}, 2.50 ; \mathrm{N}, 17.47$.

\section{5-(Pyridin-4-yl)-1,3,4-oxadiazol-2-amine (3h).}

Brown powder; yield $0.68 \mathrm{~g}(84 \%) ;$ m.p. $260-261$ ${ }^{\circ} \mathrm{C}$ (lit. m.p. $\left.262-264{ }^{\circ} \mathrm{C}^{25}\right)$; IR ( $\left.\mathrm{KBr}\right) v 3417,3383\left(\mathrm{NH}_{2}\right)$, 2358, $1665(\mathrm{C}=\mathrm{N}), 1538,1391,1340,1123(\mathrm{C}-\mathrm{O}), 1043$ $(\mathrm{N}-\mathrm{N}), 837,682,620 \mathrm{~cm}^{-1} ;{ }^{1} \mathrm{H}$ NMR $(300 \mathrm{MHz}, \mathrm{DM}-$ SO- $\left.d_{6}\right) \delta 8.74\left(\mathrm{~d}, J=7.7 \mathrm{~Hz}, 2 \mathrm{H}, \mathrm{H}-2^{\prime}, 6^{\prime} \mathrm{Ar}\right), 7.71(\mathrm{~d}, J=$ $\left.7.7 \mathrm{~Hz}, 2 \mathrm{H}, \mathrm{H}-3^{\prime}, 5^{\prime} \mathrm{Ar}\right), 7.58$ (brs, $\left.2 \mathrm{H}, \mathrm{NH}_{2}\right) ;{ }^{13} \mathrm{C} \mathrm{NMR}(75$ $\left.\mathrm{MHz}, \mathrm{DMSO}-d_{6}\right) \delta 119.2\left(\mathrm{C}-3^{\prime}, 5^{\prime} \mathrm{Ar}\right), 131.6$ (C-4' Ar), 151.1 (C-2',6' Ar), 156.2 (C-5 oxadiazole), 165.0 (C-2 oxadiazole). Anal. Calcd. for $\mathrm{C}_{7} \mathrm{H}_{6} \mathrm{~N}_{4} \mathrm{O}: \mathrm{C}, 51.85 ; \mathrm{H}, 3.73 ; \mathrm{N}$, 34.55. Found: C, 51.89; H, 3.75; N, 34.51.

\section{2. Half Maximal Inhibitory Concentration $\left(\mathrm{IC}_{50}\right)$ Identification}

DPPH free radical scavenging activities of prepared 1,3,4-oxadiazoles were evaluated and compared to those of ascorbic acid. ${ }^{28} 1 \mathrm{~mL}$ of any oxadiazole at concentrations $25,50,75$, and $100 \mu \mathrm{g} \mathrm{mL}^{-1}$ in methanol was added to $4 \mathrm{~mL}$ of $0.004 \%(\mathrm{w} / \mathrm{v})$ methanolic solution of DPPH. The mixed solutions were stored at room temperature for $30 \mathrm{~min}$ in darkness. Then, the absorbance of the solutions was read against the blank at $\lambda_{\max } 517 \mathrm{~nm}$. The inhibition percentage (I\%) was calculated according to the following equation:

$$
I \%=\frac{A(\text { blank })-A(\text { sample })}{A(\text { blank })} \cdot 100
$$

Wher $A$ (blank) and $A$ (sample) are the absorbance of control and sample solutions, respectively. A graph of $I \%$ $\left(y\right.$-axis) vs. concentration ( $x$-axis) was plotted. $\mathrm{The} \mathrm{IC}_{50}$ is 
$x$ in the equation of a straight line $y=m x+b$, while $y=50$. Finally, the $\mu \mathrm{g} \mathrm{mL}^{-1}$ units were converted to the $\mathrm{mM}$ units.

\section{3. Computational Details}

All the geometries were optimized in the gas phase and frequency calculations confirmed the nature of the stationary points. The methanol solvent was modelled using $\mathrm{C}$-PCM as implemented in Gaussian 09 program package at the B3LYP level of density functional theory using the 6-311++G (d) basis set. ${ }^{29-32} \mathrm{NCI}$ analysis was performed by the NCIPlot software. ${ }^{33}$

\section{Results and Discussion \\ 3. 1. Synthesis and Spectroscopic Characterization of 1,3,4-Oxadiazol-2- amines 3a-h}

5-Substituted 1,3,4-oxadiazol-2-amine derivatives 3a-h were synthesized via reaction of hydrazides $\mathbf{1 a}-\mathbf{h}$ and cyanogen bromide (2) under ultrasonic irradiation (Scheme 2). Potassium bicarbonate and absolute ethanol were applied as the base and the solvent, respectively.

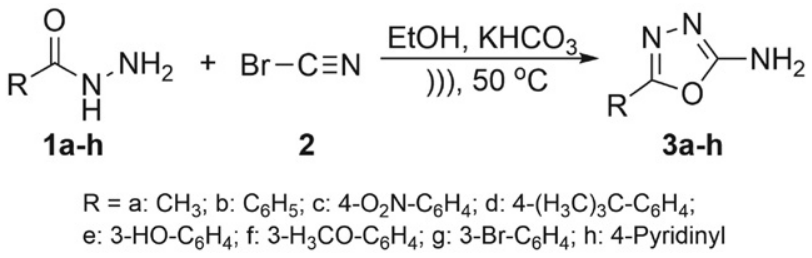

Scheme 2. Reaction scheme of the synthesis of 1,3,4-oxadiazol-2-amines $\mathbf{3 a}-\mathbf{h}$.

The interaction of $1 \mathrm{mmol}$ of both benzhydrazide (1b) and cyanogen bromide was selected as the model reaction for the preparation of 1,3,4-oxadiazoles (Table 1). Water and hydrous solvents were not used as a result of hydrolysis of cyanogen bromide to hypobromous acid and hydrogen cyanide. Absolute ethanol as a green, nontoxic, readily available, low-cost, water soluble, nonexplosive, easily removable, and recoverable solvent was selected and preferred to the toxic methanol. $2 \mathrm{~mL}$ of ethanol was used in all processes as the minimum solvent required to dissolve the most reactants and perform the reaction. Only nucleophilic attack of $\mathrm{NH}_{2}$ group of hydrazide to cyano group of cyanogen bromide occurred at room temperature (Table 1, entry 1). Intramolecular cyclization to $\mathbf{3 b}$ occurred at temperatures above $60^{\circ} \mathrm{C}$ (Table 1 , entry 2). The product yield and the reaction time were improved under refluxing conditions due to the increased solubility of the hydrazide and effective interactions between the reagents
(Table 1, entry 3 ). Higher yields were achieved at similar times in the presence of bases such as potassium bicarbonate $(1 \mathrm{mmol})$ and potassium carbonate $(0.5 \mathrm{mmol})$; increasing basicities had no effect on the yield and time. They only neutralized hydrogen bromide produced during the process so that it would not react with the hydrazide. Relative cyanogen bromide cleavage was observed in the presence of potassium hydroxide. The reaction progress was checked in the presence of $\mathrm{KHCO}_{3}$ as a nontoxic and inexpensive base under ultrasound irradiation at $50{ }^{\circ} \mathrm{C}$. 1,3,4-Oxadiazole $\mathbf{3} \mathbf{b}$ was afforded in the shortest time with the highest yield under these conditions (Table 1, entry 7).

Table 1. Optimization of reaction conditions in the synthesis of 5-phenyl-1,3,4-oxadiazol-2-amine (3b).

\begin{tabular}{lllcl}
\hline Entry & Base & $\boldsymbol{T}\left({ }^{\circ} \mathbf{C}\right)$ & Time (h) & Yield (\%) \\
\hline 1 & - & r.t. & 3 & - \\
2 & - & 60 & 9 & 68 \\
3 & - & reflux & 7 & 72 \\
4 & $\mathrm{KHCO}_{3}$ & reflux & 5 & 81 \\
5 & $\mathrm{~K}_{2} \mathrm{CO}_{3}$ & reflux & 5 & 81 \\
6 & $\mathrm{KOH}$ & reflux & 5 & 75 \\
7 & $\mathbf{K H C O}_{3}$ & )$)), \mathbf{5 0}$ & $\mathbf{3 . 5}$ & $\mathbf{9 2}$ \\
\hline
\end{tabular}

1,3,4-Oxadiazoles $\mathbf{3 a}$-h $\mathbf{h}$ were synthesized under optimized conditions. The results are given in the Table 2.

Table 2. The data of ultrasonic-assisted reactions of hydrazides $\mathbf{1 a}-\mathbf{h}$ and cyanogen bromide in ethanol yielding 1,3,4-oxadiazoles 3a-h.

\begin{tabular}{llcc}
\hline Product & $\mathbf{R}$ & Time (h) & Yield (\%) \\
\hline 3a & $\mathrm{CH}_{3}$ & 7 & 81 \\
3b & $\mathrm{C}_{6} \mathrm{H}_{5}$ & 3.5 & 92 \\
3c & $4-\mathrm{O}_{2} \mathrm{~N}-\mathrm{C}_{6} \mathrm{H}_{4}$ & 4.5 & 88 \\
3d & $4-\left(\mathrm{H}_{3} \mathrm{C}\right)_{3} \mathrm{C}-\mathrm{C}_{6} \mathrm{H}_{4}$ & 5 & 93 \\
3e & $3-\mathrm{HO}-\mathrm{C}_{6} \mathrm{H}_{4}$ & 6 & 83 \\
3f & $3-\mathrm{H}_{3} \mathrm{CO}-\mathrm{C}_{6} \mathrm{H}_{4}$ & 6 & 90 \\
3g & $3-\mathrm{Br}-\mathrm{C}_{6} \mathrm{H}_{4}$ & 3.5 & 92 \\
3h & $4-\mathrm{Pyridinyl}$ & 2.5 & 84 \\
\hline
\end{tabular}

The chemical structure of all synthesized 1,3,4-oxadiazoles $\mathbf{3 a}-\mathbf{h}$ was determined by spectral data. Recorded melting points are already in agreement with previously reported findings. ${ }^{24-27}$ The absorption bands around 1120 and $1660 \mathrm{~cm}^{-1}$ attributed respectively to $\mathrm{C}-\mathrm{O}$ and $\mathrm{C}=\mathrm{N}$ stretching vibrations confirmed the formation of 1,3,4-oxadiazole rings. In ${ }^{1} \mathrm{H}$ NMR spectra, singlet or broads peaks in the range of 6.85 to $7.58 \mathrm{ppm}$ belong to amino groups. In ${ }^{13} \mathrm{C}$ NMR spectra, signals corresponding to the asymmetric 2- and 5-carbons of 1,3,4-oxadiazole ring have appeared in the $156.2-165.0 \mathrm{ppm}$ range. 
The reaction between hydrazides $\mathbf{1}$ and cyanogen bromide is a straightforward method to synthesize 1,3,4-oxadiazole derivatives 3. Several procedures were developed for this purpose. Faizi et al. prepared 1,3,4-oxadiazole $3 \mathbf{b}$ in $62 \%$ yield from the reaction of benzhydrazide and a 1.22 molar excess of cyanogen bromide in boiling methanol for $4 \mathrm{~h} .{ }^{34}$ Some 1,3,4-oxadiazol-2-amine derivatives were synthesized via the stirring of mixture including hydrazides and 1.5 molar excess of both cyanogen bromide and potassium bicarbonate in acetonitrile water mixture (v/v 6.25:93.75) for 1 day at room temperature. ${ }^{35}$ Katritzky et al. proposed a convenient method for the preparation of 1,3,4-oxadiazole $\mathbf{3 b}$; the mixture of symmetric and asymmetric di(benzotriazolyl)methanimines prepared from 1,2,3-benzotriazole and cyanogen bromide was reacted with benzhydrazide in THF under reflux for 3 $\mathrm{h}$ to afford $\mathbf{3 b}$ in $94 \%$ yield. $^{36}$

\section{2. Antioxidant Evaluation of the Synthesized Compounds}

Free radical scavenging activity of all 1,3,4-oxadiazoles $\mathbf{3 a}-\mathbf{h}$ was assessed against DPPH. The inhibitory effects were calculated as $\mathrm{IC}_{50}$ values and are reported in Table 3.

1,3,4-Oxadiazole derivatives $\mathbf{3 a}-\mathbf{h}$ exhibited antioxidant activities in the following order: $\mathbf{3 c}>\mathbf{3 h}>\mathbf{3 a}>$ $\mathbf{3 e}>\mathbf{3 f}>\mathbf{3 b}>\mathbf{3} \mathbf{g}>\mathbf{3 d}$ which, were less than that of vitamin C. No antioxidant property was observed with derivative $3 \mathbf{d}$ containing 5-(4-(tert-butyl)phenyl) substituent. Unlike 3-(5-amino-1,3,4-oxadiazol-2-yl)phenol (3e), 1,3,4-oxadiazoles $\mathbf{3 c}$ and $\mathbf{3 h}$ with electron-withdrawing nitro and pyridinyl groups exhibited significant effects. Methylation of hydroxy group of derivative $3 \mathbf{e}$ did not significantly alter its antioxidant properties; this probably indicates a lack of hydrogen-atom donation of $\mathrm{OH}$ substituent in $\mathbf{3 e}$.

\section{3. Non-Covalent Interactions (NCI) Analysis}

We have also used NCI index, while it is a visualization index based on the electron density $(\rho)$ and the reduced density gradient $(s)$. It is based on the empirical observation that NCI can be associated with the regions of small reduced density gradient at low electronic densities. In quantum chemistry, the NCI index is used to visualize non-covalent interactions in three-dimensional space. Its visual representation arises from the isosurfaces of the reduced density gradient colored by a scale of strength. The strength is usually estimated through the product of the electron density and the second eigenvalue $\left(\lambda_{\mathrm{H}}\right)$ of the Hessian of the electron density at each point of the isosurface, with the attractive or repulsive character being determined by the sign of $\lambda_{\mathrm{H}}$. This allows for a direct representation and characterization of non-covalent interactions in the three-dimensional space, including hydrogen bonds and steric clashes. Being based on the electron density and derived scalar fields, NCI indexes are invariant with respect to the transformation of molecular orbitals. Furthermore, the electron density of a system can be calculated by X-ray diffraction experiments as well as theoretical wavefunction calculations (Figure 1). ${ }^{37-39}$

Table 3. Antioxidant activity of 1,3,4-oxadiazole derivatives 3a-h.

\begin{tabular}{lccccccccc}
\hline Products & 3a & 3b & 3c & 3d & 3e & 3f & 3g & 3h & Vitamin C \\
\hline $\mathrm{IC}_{50}(\mathrm{mM})$ & 0.237 & 0.306 & 0.114 & 0 & 0.273 & 0.284 & 0.863 & 0.222 & 0.022 \\
\hline
\end{tabular}
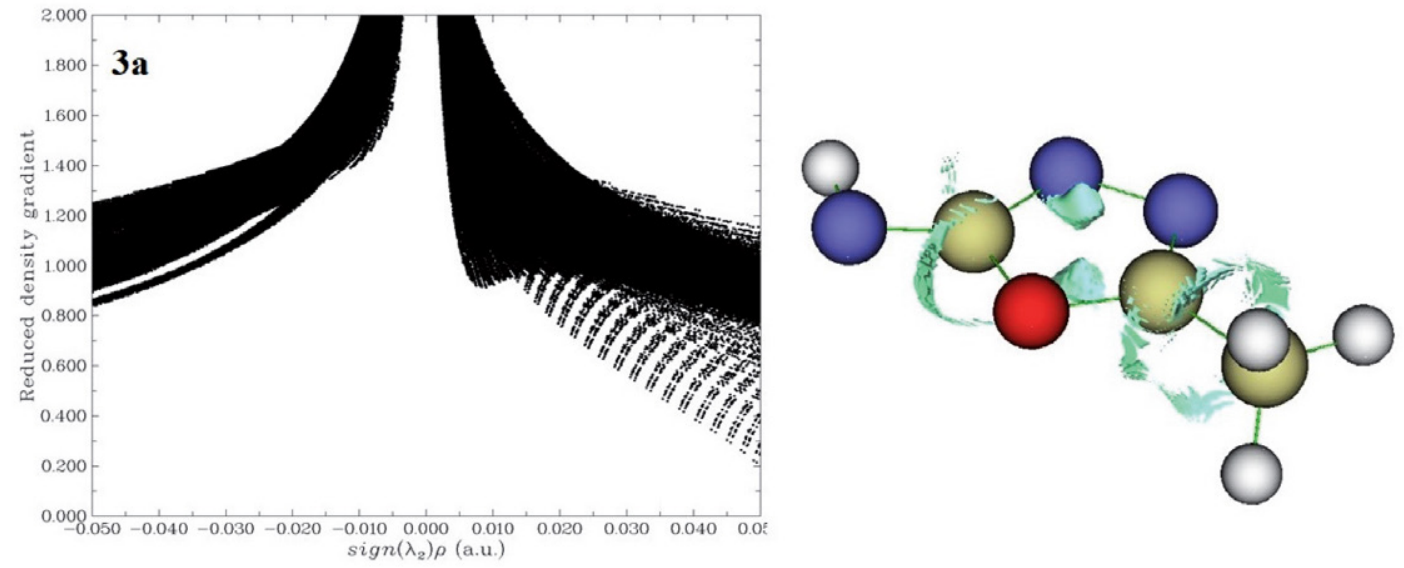

Beyzaei et al.: Ultrasound-Assisted Synthesis, Antioxidant Activity ... 

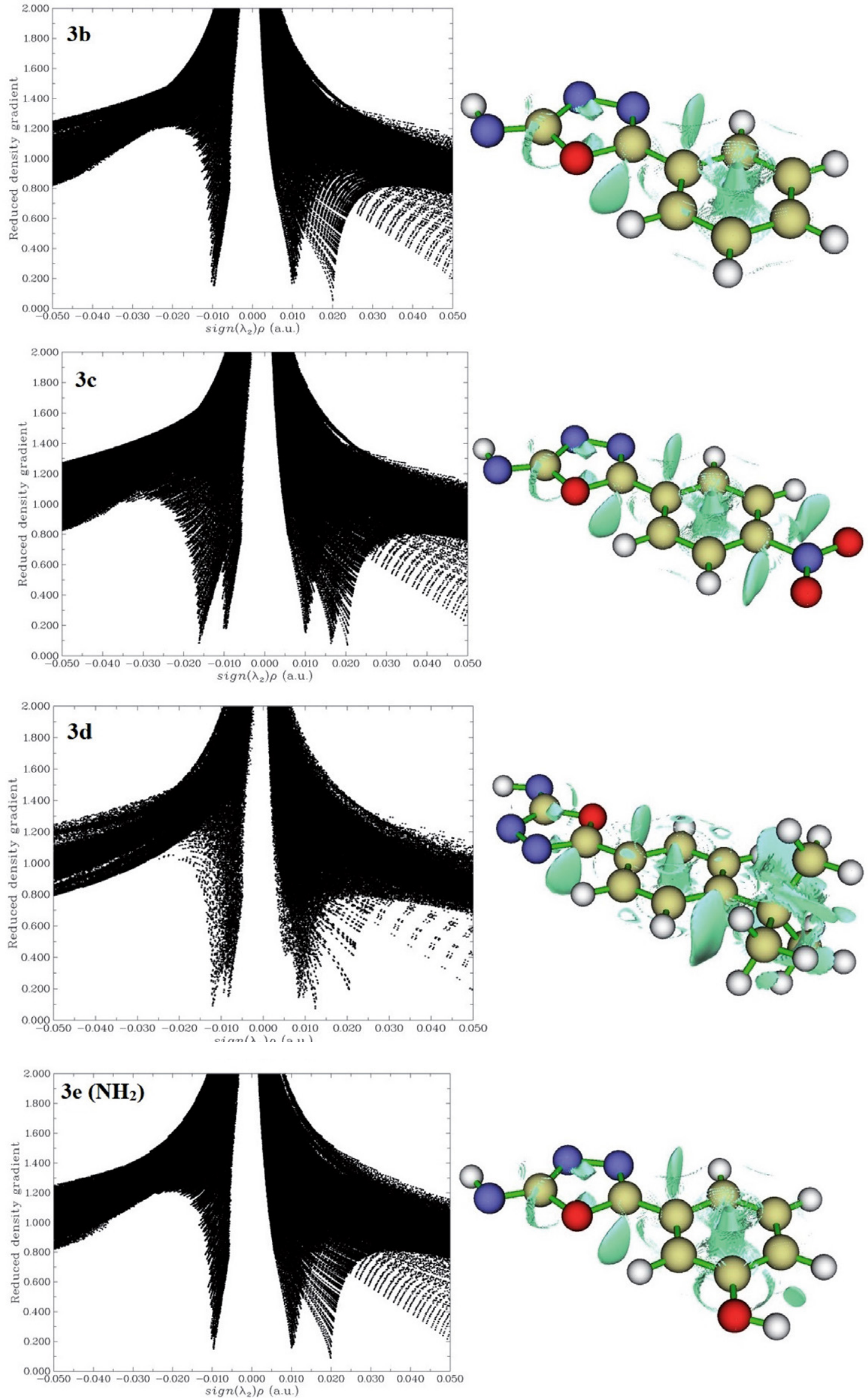

Beyzaei et al.: Ultrasound-Assisted Synthesis, Antioxidant Activity ... 

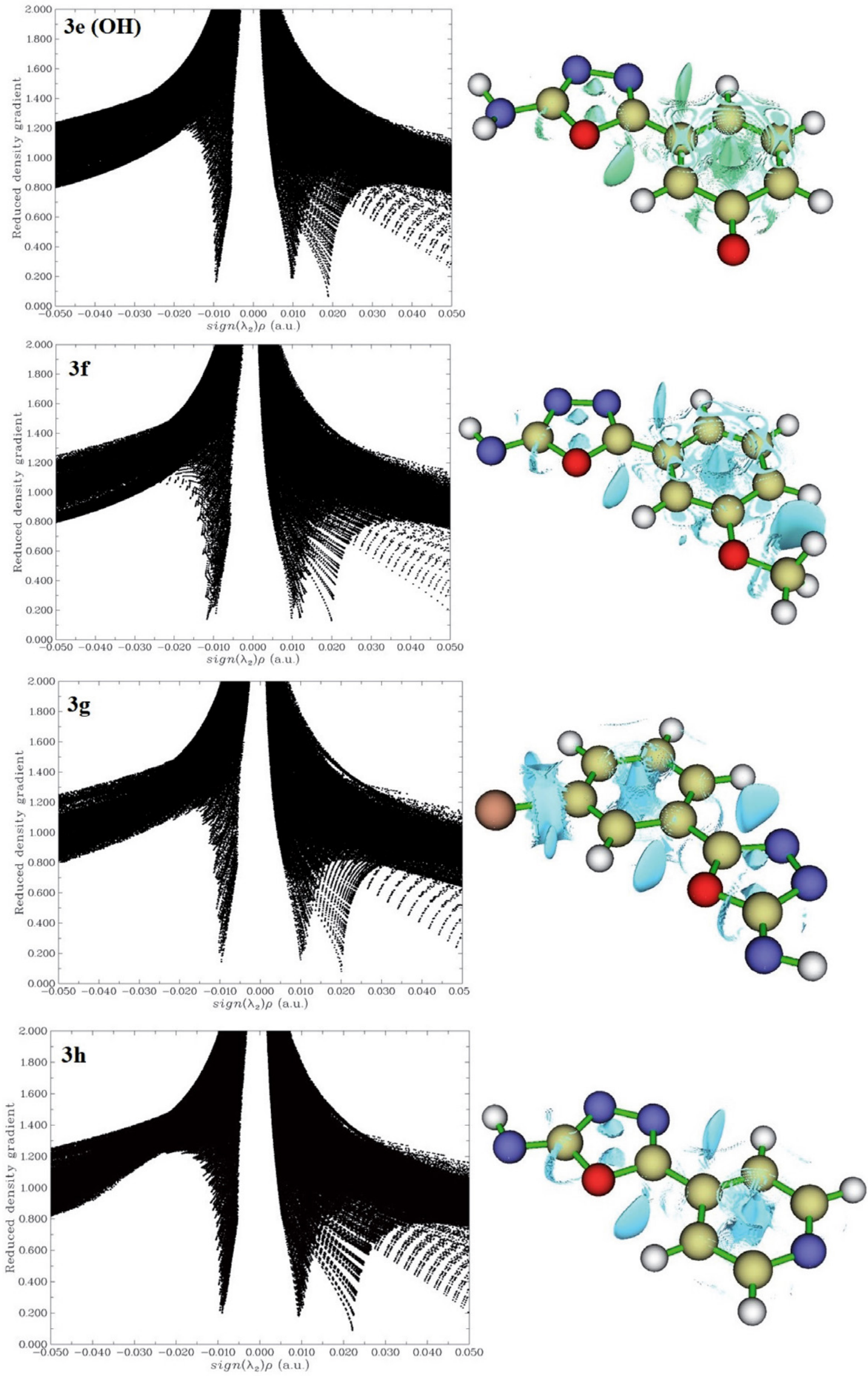

Figure 1. Plots of the reduced density gradient (RDG) versus sign $\left(\lambda_{2} \rho\right.$ and NCI isosurface (isovalue $=0.8$ au) of compounds $3 \mathbf{a}-\mathbf{h}$. 
The reduced density gradient $(s)$ is a scalar field of the electron density $(\rho)$ that can be defined as:

$$
s(r)=\frac{|\nabla \rho(r)|}{2\left(3 \pi^{2}\right)^{1 / 3} \rho(r)^{4 / 3}}
$$

\section{4. Radicalization Energy and BDE Theory}

The BDE of radicals generated from compounds 3a-h were calculated and are reported in Table 4, they were arranged according to the increasing BDEs in moving from the top to the bottom on this table. Based on calculations and BDE theory, the stability of free radicals decreases as we go from left to right across the periodic table. ${ }^{40}$ Accordingly, the product $3 \mathbf{e}$ tends to form radical from nitrogen side; oxygen atom is more electronegative than nitrogen atom and its partially empty orbital is being held more closely to the positively charged nucleus. Thus, radical $\mathbf{3 e}\left(\mathrm{NH}_{2}\right)$ is more stable than radical $3 \mathbf{e}(\mathbf{O H})$ by about $4 \mathrm{kcal} \mathrm{mol}^{-1}$. Mesomeric and/or inductive electron-withdrawing groups such as nitro destabilize free radicals; as radical $3 \mathrm{c}$ is about $3 \mathrm{kcal} \mathrm{mol}^{-1}$ less stable than radical 3b. Radical 3g containing 3-bromophenyl substituent is about $1 \mathrm{kcal} \mathrm{mol}^{-1}$ more stable than radical $\mathbf{3 b}$; this slight energy difference may be due to the dual nature of the halogen atoms (electron-withdrawing inductive effects versus electron-donating mesomeric effects). Unexpectedly, the replacement of C-4 in benzene with one nitrogen atom (4-pyridyl ring instead of a phenyl ring) in $\mathbf{3 h}$ can increase the stability of corresponding radical.

Table 4. Calculation of energy opt + frq of compounds $\mathbf{3 a}-\mathbf{h}$ using DFT method in 6-311++G (d) basis set.

\begin{tabular}{|c|c|c|c|}
\hline $\begin{array}{l}\text { Com- } \\
\text { pounds }\end{array}$ & $\begin{array}{l}\text { Reactants } \\
\text { (a.u.) }\end{array}$ & $\begin{array}{c}\text { Radicals } \\
\text { (a.u) }\end{array}$ & $\begin{array}{c}\text { BDE } \\
\left(\mathrm{kcal} \mathrm{mol}^{-1}\right)\end{array}$ \\
\hline $3 h$ & -564.5609986 & -563.9221562 & 400.88 \\
\hline $3 \mathbf{e}(\mathrm{OH})$ & -623.7550404 & -623.1156937 & 401.20 \\
\hline $3 d$ & -705.7909084 & -705.1461778 & 404.57 \\
\hline $3 \mathbf{b}$ & -548.5353695 & -547.8896743 & 405.18 \\
\hline $3 e\left(\mathrm{NH}_{2}\right)$ & -623.7550392 & -623.1091857 & 405.28 \\
\hline $3 f$ & -663.0593888 & -662.4135282 & 405.28 \\
\hline $3 g$ & -3119.639242 & -3118.991964 & 406.17 \\
\hline $3 \mathbf{a}$ & -356.7947813 & -356.1463463 & 406.90 \\
\hline $3 c$ & -753.0392 & -752.38958 & 407.64 \\
\hline
\end{tabular}

\section{Conclusions}

In this study, a new and efficient procedure was proposed for the synthesis of 1,3,4-oxadiazol-2-amines. They were prepared in good to excellent yields under ultrasound irradiation as promotion of the reaction between hydrazides and cyanogen bromide. Hydrogen-atom-donating abilities of all synthesized heterocycles were evaluated against DPPH radical. Acceptable to good antioxi- dant properties of the derivatives candidate them as potent antidiabetic, antiproliferative, anti-inflammatory and anti-neurodegenerative agents. The trend observed in the stability of radicals was not in complete agreement with the theoretical data suggesting that other mechanisms should be involved in the formation of all or some of them.

\section{Acknowledgements}

This study was funded by the University of Zabol (grant No. UOZ-GR-9718-9).

\section{References}

1. S. Goodarzi, S. Rafiei, M. Javadi, H. Khadem Haghighian, S. Noroozi, J. Food Nutr. Sec. 2018, 3, 106-112.

2. R. Gallizzi, M. Valenzise, S. Passanisi, G. B. Pajno, F. De Luca, G. Zirilli, J. Med. Case Rep. 2020, 14, 18. DOI:10.1186/s13256-020-2341-Z

3. P. Tozatti, E. J. Hopkins, C. Briggs, P. Hucl, M. T. Nickerson, Food Sci. Technol. Int. 2020, 26, 614-628.

DOI: $10.1177 / 1082013220915363$

4. T. Chaitrakoonthong, R. Ampornaramveth, P. Kamolratanakul, Int. J. Dent. 2020, 2020, 4706418. DOI:10.1155/2020/4706418

5. A. Boretti, B. K. Banik, PharmaNutrition 2020, 12, 100190. DOI:10.1016/j.phanu.2020.100190

6. Y. Baghcheghi, S. Mansouri, F. Beheshti, M. N. Shafei, H. Salmani, P. Reisi, A. Anaeigoudari, A. E. Bideskan, M. Hosseini, Int. J. Vitam. Nutr. Res. 2020, 90, 156-168. DOI:10.1024/0300-9831/a000533

7. P. Mendonca, A. G. Darwish, V. Tsolova, I. El-Sharkawy, K. F. A. Soliman, Anticancer Res. 2019, 39, 4043-4053. DOI:10.21873/anticanres. 13560

8. M. Allegra, Antioxidants 2019, 8, 549. DOI:10.3390/antiox8110549

9. Y. Luo, B. Peng, W. Wei, X. Tian, Z. Wu, Molecules 2019, 24, 1343. DOI: $10.3390 /$ molecules 24071343

10. A. Badrul, H. Ekramul, Iran. J. Pharm. Res. 2011, 7, 49-56.

11. M. M. El Sadek, S. A. Magd, S. Y. Hassan, M. Mostafa, G. Yacouat, Iran. J. Chem. Chem. Eng. 2019, 38, 229-242.

12. Z. M. M. Alzhrani, M. M. Alam, T. Neamatallah, S. Nazreen, J. Enzyme Inhib. Med. Chem. 2020, 35, 1116-1123. DOI:10.1080/14756366.2020.1759581

13. S. Nazar, N. Siddiqui, O. Alam, Arch. Pharm. (Weinheim) 2020, e1900342. DOI:10.1002/ardp.201900342

14. D. Zeng, M. W. Wang, M. Xiang, L. W. Liu, P. Y. Wang, Z. Li, S. Yang, Pest. Manag. Sci. 2020, 76, 2681-2692. DOI: $10.1002 / \mathrm{ps} .5814$

15. A. Tripathi, P. K. Choubey, P. Sharma, A. Seth, P. N. Tripathi, M. K. Tripathi, S. K. Prajapati, S. Krishnamurthy, S. K. Shrivastava, Eur. J. Med. Chem. 2019, 183, 111707.

DOI:10.1016/j.ejmech.2019.111707

16. C. S. De Oliveira, B. F. Lira, J. M. Barbosa-Filho, J. G. F. Loren- 
zo, P. F. De Athayde-Filho, Molecules 2012, 17, 10192-10231. DOI:10.3390/molecules170910192

17. K. D. Patel, S. M. Prajapati, S. N. Panchal, H. D. Patel, Synth. Commun. 2014, 44, 1859-1875.

DOI:10.1080/00397911.2013.879901

18. P. N. Khatale, T. Sivakumar, Indian J. Heterocycl. Chem. 2014, 24, 47-50.

19. J. Chauhan, M. K. Ravva, S. Sen, Org. Lett. 2019, 21, 65626565. DOI:10.1021/acs.orglett.9b02542

20. F. Golmohammadi, S. Balalaie, F. Hamdan, S. Maghari, New J. Chem. 2018, 42, 4344-4351. DOI:10.1039/C7NJ04720G

21. A. Ramazani, D. Zamanesazi, Y. Ahmadi, P. Azimzadeh Asiabi, A. Souldozi, S. J. Woo, J. Appl. Chem. Res. 2017, 11, 76-85.

22. I. O. Alisi, A. Uzairu, S. E. Abechi, Helion 2020, 6, e03683. DOI:10.1016/j.heliyon.2020.e03683

23. N. Ivanović, L. Jovanović, Z. Marković, V. Marković, M. D. Joksović, D. Milenković, P. T. Djurdjević, A. Ćirić, L. Joksović, ChemistrySelect 2016, 1, 3870-3878.

DOI:10.1002/slct.201600738

24. I. Pibiri, L. Lentini, R. Melfi, M. Tutone, S. Baldassano, P. Ricco Galluzzo, A. Di Leonardo, A. Pace, Eur. J. Med. Chem. 2018, 159, 126-142. DOI:10.1016/j.ejmech.2018.09.057

25. R. Kapoorr, S. N. Singh, S. Tripathi, L. D. S. Yadav, Synlett 2015, 26, 1201-1206. DOI:10.1055/s-0034-1380493

26. H. Rajak, B. Singh Thakur, A. Singh, K. Raghuvanshi, A. K. Sah, R. Veerasamy, P. C. Sharma, R. Singh Pawar, M. D. Kharya, Bioorg. Med. Chem. Lett. 2013, 23, 864-868.

DOI:10.1016/j.bmcl.2012.11.051

27. M. Zender, T. Klein, C. Henn, B. Kirsch, C. K. Maurer, D. Kail, C. Ritter, O. Dolezal, A. Steinbach, R. W. Hartmann, J. Med. Chem. 2013, 56, 6761-6774. DOI:10.1021/jm400830r

28. H. Beyzaei, M. Kamali Deljoo, R. Aryan, B. Ghasemi, M. M. Zahedi, M. Moghaddam-Manesh, Chem. Cent. J. 2018, 12, 114. DOI:10.1186/s13065-018-0488-0

29. M. J. Frisch, G. W. Trucks, H. B. Schlegel, G. E. Scuseria, M. A. Robb, J. R. Cheeseman, G. Scalmani, V. Barone, B. Mennucci, G. A. Petersson, H. Nakatsuji, M. Caricato, X. Li, H. P. Hratchian, A. F. Izmaylov, J. Bloino, G. Zheng, J. L. Sonnenberg, M. Hada, M. Ehara, K. Toyota, R. Fukuda, J. Hasegawa, M. Ishida, T. Nakajima, Y. Honda, O. Kitao, H. Nakai, T.
Vreven, J. A. Montgomery, J. E. Peralta, F. Ogliaro, M. Bearpark, J. J. Heyd, E. Brothers, K. N. Kudin, V. N. Staroverov, R. Kobayashi, J. Normand, K. Raghavachari, A. Rendell, J. C. Burant, S. S. Iyengar, J. Tomasi, M. Cossi, N. Rega, J. M. Millam, M. Klene, J. E. Knox, J. B. Cross, V. Bakken, C. Adamo, J. Jaramillo, R. Gomperts, R. E. Stratmann, O. Yazyev, A. J. Austin, R. Cammi, C. Pomelli, J. W. Ochterski, R. L. Martin, K. Morokuma, V. G. Zakrzewski, G. A. Voth, P. Salvador, J. J. Dannenberg, S. Dapprich, A. D. Daniels, O. Farkas, J. B. Foresman, J. V. Ortiz, J. Cioslowski, D. J. Fox, Gaussian 09, Revision A 02, Gaussian, Inc., Wallingford CT, USA, 2009.

30. S. J. A. Pople, J. Comput. Chem. 2004, 25, fmv-viii. DOI:10.1002/jcc.20049

31. M. J. S. Dewar, E. G. Zoebisch, E. F. Healy, J. J. P. Stewart, J. Am. Chem. Soc. 1985, 107, 3902-3909.

DOI:10.1021/ja00299a024

32. J. J. P. Stewart, J. Comput. Chem. 1989, 10, 209-220. DOI: $10.1002 /$ jcc. 540100208

33. J. Contreras-García, E. R. Johnson, S. Keinan, R. Chaudret, J. P. Piquemal, D. N. Beratan, W. Yang, J. Chem. Theory Comput. 2011, 7, 625-632. DOI:10.1021/ct100641a

34. M. Faizi, S. Dabirian, H. Tajali, F. Ahmadi, E. Rezaee Zavareh, S. Shahhosseini, S. A. Tabatabai, Bioorg. Med. Chem. 2015, 23, 480-487. DOI:10.1016/j.bmc.2014.12.016

35. G. D. Fallon, C. L. Francis, K. Johansson, A. J. Liepa, R. C. J. Woodgate, Aust. J. Chem. 2005, 58, 891-900. DOI:10.1071/CH05070

36. A. R. Katritzky, B. V. Rogovoy, V. Y. Vvedensky, K. Kovalenko, P. J. Steel, V. I. Markov, B. Forood, Synthesis 2001, 2001, 897-903. DOI:10.1055/s-2001-13400

37. E. Pastorczak, C. Corminboeuf, J. Chem. Phys. 2017, 146, 120901. DOI:10.1063/1.4978951

38. E. R. Johnson, S. Keinan, P. Mori-Sánchez, J. Contreras-García, A. J. Cohen, W. Yang, J. Am. Chem. Soc. 2010, 132, 6498-6506. DOI:10.1021/ja100936w

39. J. Contreras-García, W. Yang, E. R. Johnson, J. Phys. Chem. A 2011, 115, 12983-12990. DOI:10.1021/jp204278k

40. I. Hamlaoui, R. Bencheraiet, R. Bensegueni, M. Bencharif, J. Mol. Struct. 2018, 1156, 385-389.

DOI:10.1016/j.molstruc.2017.11.118

\section{Povzetek}

Razvoj sinteznih postopkov za pripravo 1,3,4-oksadiazolskih derivatov je bil vedno v središču pozornosti raziskovalcev, saj tovrstni heterocikli izkazujejo množico uporabnih bioloških aktivnosti. V tej študiji smo z reakcijo med različnimi hidrazidi in cianogen bromidom s pomočjo ultrazvočnega valovanja, ob prisotnosti etanola kot topila in kalijevega hidrogenkarbonata kot baze, uspešno sintetizirali serijo 1,3,4-oksadiazol-2-aminov, ki smo jih izolirali z 81-93 \% izkoristki. Antioksidativne lastnosti pripravljenih spojin smo določili s pomočjo metode lovljenja DPPH prostih radikalov; to je ena izmed najbolj osnovnih stopenj pri identifikaciji povezanih bioloških učinkov. Izmerjene $\mathrm{IC}_{50}$ vrednosti so bile $\mathrm{v}$ območju 0.237 to $0.863 \mathrm{mM}$. Sintetizirani 1,3,4-oksadiazoli lahko služijo kot spojine, ki ščitijo pred oksidativnim stresom, in se lahko uporabljajo za zdravljenje raka, kandidiaze, sladkorne bolezni ter nevrodegenerativnih in inflamatornih obolenj. S pomočjo teorije gostotnega polja (DFT) smo izračunali energije disociacije vezi (BDE) in elektronske gostote, ki temeljijo na nekovalentnih interakcijah (NCI). Ugotovili smo, da reverzibilne sile dipol-dipol igrajo ključno vlogo pri večini interakcij.

Except when otherwise noted, articles in this journal are published under the terms and conditions of the Creative Commons Attribution 4.0 International License 